\title{
THE EARLY MEDIEVAL ORIGIN OF PERTH, SCOTLAND
}

\author{
D W Hall ${ }^{1} \bullet \mathrm{G} \mathrm{T} \mathrm{Cook}{ }^{2,3} \bullet \mathrm{M} \mathrm{A} \mathrm{Hall}^{4} \bullet \mathrm{G} \mathrm{K} \mathrm{P} \mathrm{Muir}{ }^{2} \bullet \mathrm{D} \mathrm{Hamilton}^{5} \bullet \mathrm{E} \mathrm{M} \mathrm{Scott}^{6}$
}

\begin{abstract}
The radiocarbon results (and Bayesian modeling) of 15 samples of carbonized food residues removed from the external surface of rim sherds of cooking pots indicate that shellyware pottery first appeared in Perth, Scotland, around cal AD 910-1020 (95\% probability) and that it had disappeared by cal AD 1020-1140 (95\% probability). Previously, it had been suggested that this pottery could not date to before $\mathrm{AD} 1150$. These data, together ${ }^{2}$ ith ${ }^{14} \mathrm{C}$ analyses carried out on leather artifacts and a sample of wattle from a ditch lining, also demonstrate that there was occupation in Perth about $100 \mathrm{yr}$ or more prior to the granting of royal burgh status to Perth in the $1120 \mathrm{~s}$.
\end{abstract}

\section{INTRODUCTION}

The excavation site of 75 High Street in the heart of Perth commenced in the 1970s. Of major importance has been the evidence from the early phases-of occupation prior to the foundation of the burgh in the early 12th century. Recent dendrochronological analysis of the extant timbers from the early phases has failed to provide ring sequences that fit into the existing dendrochronological curve for Scotland, and it has been suggested that this may imply that they are of an early date. For many years, it has been argued that the ceramics from the early phases of this excavation may be of preburghal date, but expert analysis of the imported wares has argued that they date to no earlier than AD 1150 (A Vince, personal communication). Analysis of some of these fabrics has suggested that they all belong to the London shelly-sandyware tradition (L Blackmore and A Vince, personal communication). In England, the early version of this fabric is dated to the 10th and 11th centuries, with a suggestion that in Oxford and London it disappears from the archaeological record by the early years of the 11th century (Mellor 1980:17-27; Vince 1985). The various stages of the shellyware industry have been discussed in detail by Vince and others (see especially Vince [1991] and Steedman et al. [1992] for London excavations, and Blackmore and Vince [1994] and Ludtke [1992] for their occurrence in Norway and northwest Germany). Vince's analysis identifies the ware from Perth as London shelly-sandyware, a type that appears in London in the mid-12th century and which has been precisely defined via petrology. We acknowledge that the earlier (pre-12th century) shellywares do have a different clay source and a different fabric composition as defined by petrology and that the products have different forms, but this does not automatically mean that the perceived London chronology for the development of the whole shellyware tradition has to hold for the whole of the United Kingdom. Vince's main concern with the arguments presented here is that shelly-sandyware is dated by dendrochronology and associated artifacts from excavations in London only to the late 12th century (in waterside revetment dumping, particularly from Billingsgate; L Blackmore, personal communication; and as summarized in print in the Museum of London's Medieval Finds from Excavations in London catalog series, e.g. Egan and Pritchard 1991:1-12). However, the potsherds are all from the banks dumped behind these timber revetments (which provided the material for the dendrochronology), and there must surely be a very strong chance that they originate from earlier deposits. There is certainly, then, an absence of evidence issue here—but not necessarily unequivocal evidence of absence.

\footnotetext{
'SUAT Ltd., 55 South Methven Street, Perth, Scotland PH1 5NX, United Kingdom.

${ }^{2}$ SUERC, Scottish Enterprise Technology Park, Rankine Avenue, East Kilbride, Scotland G75 0QF, United Kingdom.

${ }^{3}$ Corresponding author. Email: g.cook@ suerc.gla.ac.uk.

${ }^{4}$ Perth Museum and Art Gallery, 78 George Street, Perth, Scotland PH1 5LB, United Kingdom.

${ }^{5}$ English Heritage, 23 Savile Row, London, England W1S 2ET, United Kingdom.

${ }^{6}$ Department of Statistics, University of Glasgow, Glasgow, Scotland G12 8QW, United Kingdom.
} 
Equally, although the bulk of the other imports from Perth are of the type one would expect alongside later shellywares, this is also not conclusive, for there is at least 1 sherd of a Pingsdorf pitcher and 87 sherds of Thetford ware dating to the 11th/12th centuries (Rogerson and Dallas 1984:117-28), including a fragment from a tubular spouted pitcher from Period 1 (2) at 75 High Street.

Most of the shellyware sherds in the assemblage from 75 High Street are from cooking pots, with 1 virtually complete example giving the best idea of form (see Hall et al. 2005 for an illustration). There is also a fragment of a tripod leg with a central thumbed strip, which is paralleled by material from excavations at Billingsgate in London. The vessels are handmade but have wheel-thrown rims, and on the basis of the revetment-based chronology, this manufacturing technique suggests that they belong to the mid to late 12th century phase of this industry. This dating of the early phases of 75 High Street, Perth, by reference to the form of the pottery, was not readily accepted by those involved in the ongoing research due to the narrow time gap that was then created between Phases I and II (Phase II was already dendrochronologically dated to AD $1150 / 51$ by a timber from one of the buildings). Breaking this impasse has been made possible by dating those imported sherds that had carbonized food residues on their surfaces. The samples from Perth High Street were ideal for radiocarbon dating as they had thick (1- to 2-mm), highly carbonized encrustations of food on the external surface. Food residues are susceptible to geochemical contamination (Bonsall et al. 2002); however, this is unlikely to be an issue here because of the degree of carbonization (Hedges et al. 1992). Fifteen carbonized rim sherds of shelly-sandyware fabric from the earliest phases (all from contexts associated with the earliest buildings on the site) were chosen for analysis. In addition, 3 leather samples from other early phases of the site were also analyzed. The result for an earlier radiometric analysis of the wood from the wattle lining of a ditch from the neighboring site at 80-86 High Street, Perth, is also included for comparison. The study was designed to confirm or refute Vince's argument that the shellyware pottery could not be earlier in date than the mid-12th century, and to confirm occupation of the area now known as Perth, prior to its designation as a royal burgh in the early 12 th century.

\section{METHODS}

All sample pretreatments and preparations to graphite for accelerator mass spectrometry (AMS) analysis were undertaken at SUERC.

The highly carbonized food residues were carefully scraped from the rim sherds using a scalpel, taking care not to incorporate mineral material from the sherd. This negates any possibility of incorporating contamination from organic coatings on the clay minerals (De Atley 1980) as such contaminants have been shown to survive firing (Johnson et al. 1988). The residue samples were then pretreated as per charcoal samples using a standard acid-alkali-acid pretreatment scheme, followed by washing with reverse osmosis water and drying. The leather samples underwent Soxhlet extraction using solvents of increasing polarity (hexane, ethanol, and then water), and then a brief alkali followed by an acid extraction. The samples were then washed in reverse osmosis water and dried. The samples were all combusted in evacuated sealed quartz tubes using copper oxide as the oxidant and silver foil to react with and remove gaseous contaminants (mainly halides). The tubes were opened under vacuum, the $\mathrm{CO}_{2}$ recovered and purified, and then converted to graphite according to the method of Slota et al. (1987).

The first batch of 10 samples were ${ }^{14} \mathrm{C}$ dated at the University of Arizona, NSF-AMS Laboratory, using either the National Electrostatic Corporation (NEC) 3MV or General Ionex 2.5MV terminal voltage instruments, with carbon in the $3+$ charge state. The second batch of 5 samples was analyzed at the SUERC AMS facility (NEC 5MV terminal voltage instrument), with carbon in the 4+ charge 
state. When there was sufficient $\mathrm{CO}_{2}, \delta^{13} \mathrm{C}$ analysis was also undertaken. The isotopic composition of the $\mathrm{CO}_{2}$ was measured on a VG SIRA 10 stable isotope mass spectrometer, using NBS standards 22 (oil) and 19 (marble) to determine the $45 / 44$ and $46 / 44$ atomic mass ratios, from which the $\delta^{13} \mathrm{C}$ value was calculated.

\section{RESULTS}

The results for the ${ }^{14} \mathrm{C}$ analysis of the carbonized residues are presented in Table 1, and those for the leather artifacts and wattle sample in Table 2 . The ${ }^{14} \mathrm{C}$ ages were calibrated using OxCal v 3.10 (Bronk Ramsey 1995, 2001), with a Bayesian approach applied to the carbonized residue results. The model that was employed defined the 15 residue measurements as a single phase, but included the definition of 2 contexts with 3 measurements in each. The start and end dates were then estimated as boundaries. The model assumes that the 15 ages are uniformly distributed over the historic use/life of the fabric. Figure 1 is a graphical representation of the results. The representations shown in black outline are derived from the probability method (Stuiver and Reimer 1993), while the black portions are the posterior density estimates derived from the Bayesian modeling. The brackets down the left side and the OxCal keywords define the model exactly.

Table $1{ }^{14} \mathrm{C}$ ages of carbonized residues.

\begin{tabular}{llllcr}
\hline Laboratory code & \multicolumn{2}{l}{ Sample code } & $\delta^{13} \mathrm{C}(\% o)$ & Age (BP) $\pm 1 \sigma$ & Calibrated range AD \\
\hline AA-52358 & S.1 & C. 5097 & -26.3 & $960 \pm 40$ & $990(95.4 \%) 1170$ \\
AA-52359 & S.2 & C. 4715 & -26.0 & $1065 \pm 40$ & $890(95.4 \%) 1030$ \\
AA-52360 & S.3 & C. $3748 / 1$ & -27.1 & $1050 \pm 40$ & $890(95.4 \%) 1040$ \\
AA-52361 & S.4 & C. $3748 / 2$ & -26.7 & $1065 \pm 55$ & $860(90.6 \%) 1050$ \\
AA-52362 & S.5 & C. 2386 & -26.7 & $975 \pm 45$ & $980(95.4 \%) 1170$ \\
AA-52363 & S.6 & C. 4513 & -26.8 & $890 \pm 45$ & $1020(95.4 \%) 1230$ \\
AA-52364 & S.7 & C. 4534 & -26.8 & $1085 \pm 40$ & $880(95.4 \%) 1030$ \\
AA-52365 & S.8 & C. 3625 & -26.9 & $1050 \pm 70$ & $810(95.4 \%) 1160$ \\
AA-52366 & S.9 & C. $2394 / 1$ & -26.9 & $1065 \pm 60$ & $800(90.5 \%) 1050$ \\
AA-52367 & S.10 & C. $2394 / 2$ & -26.9 & $1020 \pm 45$ & $890(95.4 \%) 1160$ \\
SUERC-4835 & S.11 & C. $2394 / 3$ & -26.8 & $1065 \pm 40$ & $890(95.4 \%) 1030$ \\
SUERC-4836 & S. 12 & C. $3748 / 3$ & -26.4 & $1030 \pm 35$ & $890(92.1 \%) 1050$ \\
SUERC-4837 & S. 13 & C. 3728 & -24.2 & $955 \pm 40$ & $990(95.4 \%) 1180$ \\
SUERC-4838 & S.14 & C. 2387 & -26.0 & $910 \pm 35$ & $1030(95.4 \%) 1210$ \\
SUERC-4839 & S. 15 & C. 3733 & -26.0 & $1010 \pm 40$ & $960(92.8 \%) 1160$ \\
\hline
\end{tabular}

Table $2{ }^{14} \mathrm{C}$ data for leather artifacts from 75 Perth High Street and wattle sample from $80-86$ Perth High Street.

\begin{tabular}{llllrr}
\hline Laboratory code & Sample code & Sample type & \multicolumn{1}{l}{$\begin{array}{l}\delta^{13} \mathrm{C} \\
(\%)\end{array}$} & \multicolumn{1}{l}{$\begin{array}{l}\text { Age (BP) } \\
\pm 1 \sigma\end{array}$} & \multicolumn{1}{c}{ Calibrated range AD } \\
\hline SUERC-9445 & PHS A9886a & Leather & $-26.5^{\mathrm{a}}$ & $975 \pm 35$ & $990(95.4 \%)$ \\
SUERC-9447 & PHS A12003a & Leather & $-26.5^{\mathrm{a}}$ & $1060 \pm 35$ & $890(95.4 \%) 1030$ \\
SUERC-9448 & PHS A12003d & Leather & -26.2 & $910 \pm 35$ & $1030(95.4 \%) 1210$ \\
GU-3479 & PE12 1042 & Wattle & -26.6 & $990 \pm 35$ & $960(93.9 \%) 1170$ \\
\hline
\end{tabular}

${ }^{a}$ Average value based on all other leather samples. 


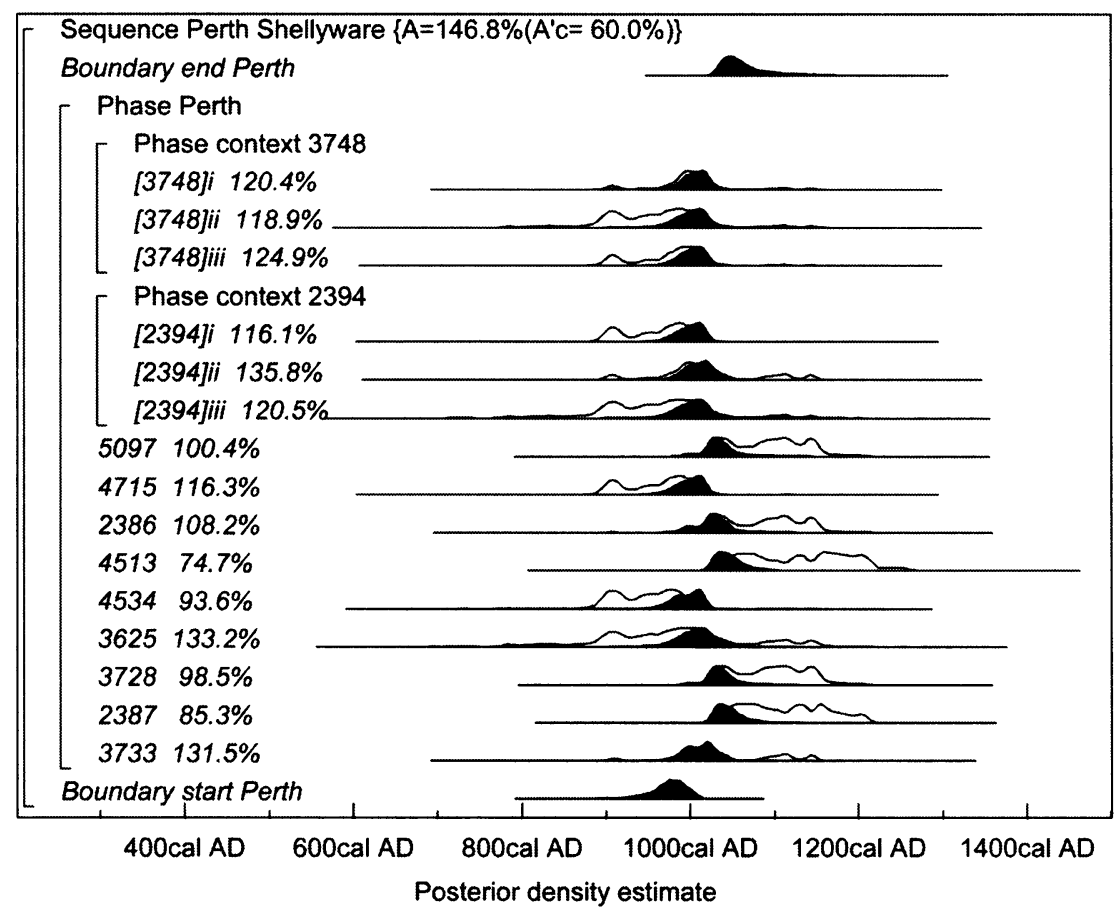

Figure 1 Graphical representation of calibration of ${ }^{14} \mathrm{C}$ results for carbonized residues

The 15 carbonized pottery sherds produced uncalibrated ${ }^{14} \mathrm{C}$ ages ranging from $890 \pm 45$ to $1085 \pm$ $40 \mathrm{BP}$. These are all from the external surfaces of the pots, and it could be argued that these could be contaminated, e.g. by soot from fuel that was much older than the age of the food residue. This argument can be countered as follows:

1. Geochemical contamination is unlikely because of the highly carbonized nature of the residues.

2. The sherds from which the carbonized residues were taken all derived from the rims of the pots, and therefore as far from the fire as possible.

3. The residues were 1- to 2-mm thickness and not a soot-type deposit. It is likely that any contamination from soot would be minimal. Therefore, any potential effect from the fuel (e.g. oldwood effect) would be minimal.

4. There is no evidence that coal was in use in Perth before the 18th century.

5. This area has no significant peat deposits that could have been used as fuel.

6. The ages form a very coherent group that is supported by measurements made on other materials, as discussed later.

Some of these issues have also been confronted in a parallel case study of the ${ }^{14} \mathrm{C}$ analysis of E-ware residues from the Loch Glashan excavations (Crone and Campbell 2005).

The model with the carbonized food residues (Figure 1) is in good agreement $(A=146.8 \%)$. It suggests that the shelly-sandyware first appeared in Perth around cal AD 910-1020 (95\% probability) and that it had disappeared by cal AD 1020-1140 (95\% probability). It was also of interest to model the probability that the use of the shellyware predated the 12th century. Figure 2 shows the posterior density estimate based on the carbonized residues, with the cutoff date of cal 
AD 1100 marked by the vertical line. It is clear that the vast majority of the probability mass ( $>90 \%)$ predates the 12 th century.

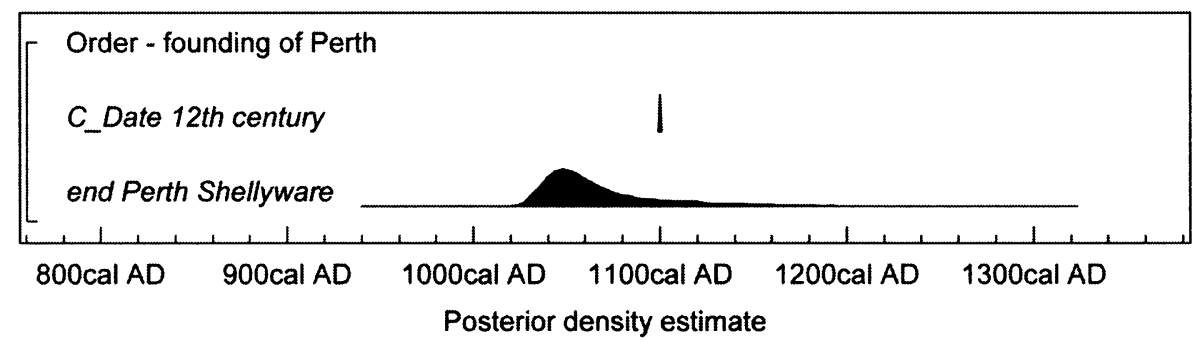

Figure 2 Graphical representation of the probability distribution for the use of shellyware in Perth to predate the 12 th century $\mathrm{AD}$.

The leather samples cover a similar age span to the carbonized residues, and provide confirmation of these ages. We also analyzed 4 other leather samples that produced somewhat later ages (between 700 and $840 \mathrm{BP}$ ). These are regarded as reflecting the complexity of the phasing of this site and the need for further examination of this phasing, rather than any problems with the samples per se.

\section{DISCUSSION}

The first and most obvious conclusion to reach from this group of measurements is that there is strong evidence for occupation in Perth prior to its formal grant of burgh status. Many of the results are indicative of occupation in Perth $\sim 100 \mathrm{yr}$ or more prior to the founding of the burgh of Perth in the $\mathrm{AD} 1120$ s. This should not be an enormous surprise, as the view that King David I founded his burghs on "green-field" sites is long outdated.

The Bayesian modeling of the food residues demonstrates that shellyware pottery first appeared at least $100 \mathrm{yr}$ earlier than the founding of the burgh of Perth, and demonstrates conclusively that this fabric was in use in Perth much earlier than was predicted (by at least $130 \mathrm{yr}$ ). We are confident that the ages of the carbonized food residues are not compromised by contamination by smoke from "old fuel," and this is supported by 3 analyses of small pieces of leather, also taken from the earliest contexts. These leather samples came from shoes that were well preserved in the anoxic conditions present on the site.

The combination of carbonized food residue ages and the ages of the leather samples (all from early phases at 75 High Street), together with the single ${ }^{14} \mathrm{C}$ age of $990 \pm 50 \mathrm{BP}$ (AD 960-1170) from the wattle lining of a ditch (from 80-86 High Street), gives us some interesting possibilities for the nature of the early settlement of Perth. These dates provide a solid foundation on which to explore the nature of the early settlement of Perth, including its use of imported cooking vessels. The nature of the settlement remains unclear: Was it primarily religious (the 10/11th century ditch is likely to have defined an early church site, corroborated by a piece of sculpture) or secular (and, for example, based on seasonal market activity or estate administration)? Imported cooking vessels would be valuable to both types of communities, though the long-distance trade links around the North Sea littoral, implied by such pottery, may favor a secular interpretation or at least a strong economic impetus supported by the church. The recent ${ }^{14} \mathrm{C}$ dating of sherds of similar fabrics from Billingsgate in London to a similar date bracket (Hall et al. 2005) opens the way for a similar analysis of shellyware sherds from Norway, where the same material is found. 


\section{ACKNOWLEDGMENTS}

We thank Historic Scotland for funding this study, the staff of the University of Arizona and SUERC AMS laboratories for undertaking the ${ }^{14} \mathrm{C}$ measurements, and the anonymous referees for their comments. Although we remain at variance with Alan Vince over the interpretation of the shelly-sandywares from Perth, we are grateful to him for the helpful way he has expressed his skepticism, both verbally and in writing. In lieu of a right of reply, we acknowledge his variant position and trust that we have not misrepresented his views in our discussion.

\section{REFERENCES}

Blackmore L, Vince A. 1994. Medieval pottery from south-east England found in the Bryggen excavations 1955-68. In: The Bryggen Papers: Supplementary Series 5. Oslo: Norwegian University Press. p 9-60.

Bonsall C, Cook G, Manson JL, Sanderson D. 2002. Direct dating of Neolithic pottery: progress and prospects. Documenta Praehistoria XXIX:47-59.

Bronk Ramsey C. 1995. Radiocarbon calibration and analysis of stratigraphy: the OxCal program. Radiocarbon 37(2):425-30.

Bronk Ramsey C. 2001. Development of the radiocarbon program. Radiocarbon 43(2A):355-63.

Crone A, Campbell E. 2005. A Crannog of the First Millennium AD: Excavations by Jack Scott at Loch Glashan, Argyll, 1960. Edinburgh: Society of Antiquaries of Scotland. $176 \mathrm{p}$.

De Atley SP. 1980. Radiocarbon dating of ceramic materials: progress and prospects. Radiocarbon 22(3): 987-93.

Egan G, Pritchard F. 1991. Dress Accessories c.1150c.1450 (Medieval Finds from Excavations in London). 3rd edition. London: Museum of London. $426 \mathrm{p}$.

Hall MA, Hall DW, Cook GT. 2005. What's cooking? New radiocarbon dates from the earliest phases of the Perth High Street excavations and the question of Perth's early medieval origin. Proceedings of the Society of Antiquaries for Scotland 135:273-85.

Hedges REM, Tiemei C, Housley RA. 1992. Results and methods in the radiocarbon dating of pottery. Radiocarbon 34(3):906-15.
Johnson JS, Clark J, Miller-Antonio S, Robbins D, Schiffer MB, Skibo JM. 1988. Effects of firing temperature on the fate of naturally occurring organic matter in clays. Journal of Archaeological Science 15(4):403-14.

Ludtke H. 1992. English pottery found in Hedeby, Schleswig and Hollingstedt. In: Gaimster D, Redknap M, editors. Everyday and Exotic Pottery from Europe: Studies in Honour of John G. Hurst. Oxbow Monographs in Archaeology 23. Oxford: Oxbow. p 70-5.

Mellor M. 1980. Late Saxon pottery from Oxfordshire: evidence and speculation. Medieval Ceramics 4:1727.

Rogerson A, Dallas C. 1984. Excavations in Thetford 1948-59 and 1973-80. Norwich: East Anglian Archaeology. Report no 22. p 117-28.

Slota Jr PJ, Jull AJT, Linick TW, Toolin LJ. 1987. Preparation of small samples for ${ }^{14} \mathrm{C}$ accelerator targets by catalytic reduction of CO. Radiocarbon 29(2):303-6.

Steedman K, Dyson T, Schofield J. 1992. Aspects of Saxo-Norman London III: The Bridgehead and Billingsgate to 1200. London: London and Middlesex Archaeological Society. Special Paper 14. 216 p.

Stuiver M, Reimer PJ. 1993. Extended ${ }^{14} \mathrm{C}$ data base and revised CALIB $3.0{ }^{14} \mathrm{C}$ age calibration program. $R a$ diocarbon 35(1):215-30.

Vince A. 1985. The Saxon and medieval pottery of London: a review. Medieval Archaeology 29:25-93.

Vince A. 1991. Early medieval London: refining the chronology. London Archaeologist 6(10):263-71. 